\title{
Persepsi Siswa Madrasah Aliyah Rejang Lebong Terhadap Program Studi Komunikasi dan Peyiaran Islam Jurusan Dakwah Stain Curup
}

\author{
Bakti Komalasari \\ Sumarni Sumai \\ Adinda Tessa Naumi \\ STAIN Curup \\ adindatessa@gmail.com
}

\begin{abstract}
The development of STAIN Curup has shown a significant improvement both in terms of the number of students and the institutional aspect. The existence of STAIN Curup began to be felt as part of the world of education not only for the environment but also for the nearest regency areas such as Lubuk. Linggau, Kepayang, Lebong, Bengkulu City, Palembang, Bukit Tinggi and even from Java Island. This development is not directly proportional to the growth of the number of new students each year in the Communication Studies and Islamic Broadcasting Program (Prodi KPI), which is still far tertiggal compared with other Prodi-Prodi in STAIN Curup. Therefore, this research tries to find a solution about it, by focusing on two research problems (1) How is the perception of $M A$ students about KPI Study, Department of Propagation, STAIN Curup? (2) What factors influence student's perception about KPI Prodi Major Dakwab STAIN Curup?

This research sees information about the KPI Prodi obtained from family / friends I neighbors who are currently or have completed education at STAIN Curup, mass media that is through advertisement acceptance new newspaper Daily Newspaper Radar Pat Petulai, and Radio Pesona FM, and from brochure of student admission new. Then the information will be organized and interpreted. Based on the result of the research, the perception of MAN Curup and MA ArRahmah students toward KPI Study Program of STAIN Curup Dakwah, among others: Prodi KPI is good enough, KPI Prodi still doubt, and not too familiar with Prodi KPI. The formation of MA students' perceptions of KPI study is influenced by several factors. Factors that influence the perception of $M A$ students include: experience, motivation, interests and needs, expectations, and stereotypes.
\end{abstract}

Keywords: Perception, Prodi KPI, MA students 


\begin{abstract}
Abstrak
Perkembangan STAIN Curup semakin menunjukkan peningkatan yang sangat berarti, baik dari segi jumlah mahasiswanya maupun dari segi kelembagaannya (institusi). Keberadaan STAIN Curup mulai dirasakan sebagai bagian dari dunia pendidikan bukan hanya bagi lingkungan sekitar tetapi juga bagi daerah-daerah kabupaten terdekat, seperti Lubuk Linggau, Kepayang, Lebong, Kota Bengkulu , Palembang, Bukit Tinggi, dan bahkan dari Pulau Jawa. Perkembangan ini tidak berbanding lurus dengan pertumbuhan jumlah mahasiswa baru setiap tahunnya pada Program Studi Komunikasi dan Penyiaran Islam (Prodi KPI), yang masih jauh tertiggal dibandingkan dengan Prodi-Prodi lainnya yang ada di STAIN Curup. Untuk itu penelitian ini mencoba mencari solusi mengenai hal tersebut, dengan memfokuskan ke dua permasalahn penelitian (1) Bagaimana persepsi siswa MA tentang Prodi KPI, Jurusan dakwah, STAIN Curup?(2) Faktor-faktor apakah yang mempengaruhi persepsi siswa tentang Prodi KPI Jurusan Dakwah STAIN Curup?

Penelitian ini melihat informasi mengenai Prodi KPI didapat dari keluarga/teman/tetangga yang sedang maupun telah selesai menempuh pendidikan di STAIN Curup, media massa yaitu melalui iklan penerimaan mahasiswa baru Surat Kabar Harian Radar Pat Petulai, dan Radio Pesona FM, serta dari brosur penerimaan mahasiswa baru. Kemudian informasi tersebut akan diorganisir dan diinterpretasikan. Berdasarkan hasil penelitian, persepsi siswa MAN Curup dan MA Ar-Rahmah terhadap Prodi KPI Jurusan Dakwah STAIN Curup, antara lain: Prodi KPI sudah cukup baik, Prodi KPI masih diragukan, serta belum terlalu mengenal Prodi KPI. Terbentuknya persepsi siswa MA terhadap Prodi KPI dipengaruhi oleh beberapa faktor. Faktor-faktor yang mempengaruhi persepsi siswa MA antara lain: pengalaman, motivasi,minat dan kebutuhan, harapan, serta stereotip.
\end{abstract}

Kata kunci: Persepsi, Prodi KPI, siswa MA

\title{
Pendahuluan
}

Secara historis, program studi Komunikasi Penyiaran Islam Jurusan Dakwah Sekolah Tinggi Agama Islam Negeri (STAIN) Curup lahir 
melalui sejarah yang cukup panjang. Mulanya adalah Fakultas Syariah IAIN Raden Fatah Curup yang berstatus sebagai fakultas jauh dari IAIN Raden Fatah Palembang atau dengan kata lain IAIN Raden Fatah cabang Pelembang di Curup. Sementara itu IAIN Raden Fatah Palembang sendiri merupakan cabang IAIN Sunan Kalijaga Yogyakarta. ${ }^{1}$

STAIN Curup terletak di kelurahan Dusun Curup, Curup Utara, Rejang Lebong Dusun Curup. Kelurahan tersebut berjarak sekitar $1 \mathrm{~km}$ dari pusat keramaian ibukota k2002bupaten Rejang Lebong.Kampus STAIN Curup berlokasi di tengah-tengah kehidupan masyarakat yang ramah, berkebudayaan Suku Rejang Rejang, dan masyarakat yang menjunjung tinggi etika yang bernuansa Islam.

Pada awal perkembangannya, STAIN Curup hanya mengelola Jurusan Dakwah, Komunikasi dan Penyiaran Islam. Untuk tetap berdiri sebagai salah satu Perguruan Tinggi yang berbasiskan Islam, dan untuk mewujudkan visi menjadi pusat pendidikan, penelitian, pengembangan ilmu pengetahuan dan kebudayaan Islam serta membangun masyarakat berdasarkan iman, ilmu, dan amal secara integral, pada tahun akademik 2002 STAIN Curup membuka jurusan baru, yakni Jurusan Tarbiyah (ilmu kependidikan). Pada perkembangannya tahun 2008 STAIN Curup menambah jurusan baru yakni Jurusan Syariah.Dengan demikian STAIN Curup telah memiliki tiga jurusan yakni; Jurusan Dakwah, Jurusan Tarbiyah, dan Jurusan Syariah.

Dengan dibukanya tiga Jurusan ini, perkembangan STAIN Curup semakin menunjukkan peningkatan yang sangat berarti, baik dari segi jumlah mahasiswanya maupun dari segi kelembagaannya (institusi). Keberadaan STAIN Curup mulai dirasakan sebagai bagian dari dunia pendidikan bukan hanya bagi lingkungan sekitar tetapi juga bagi daerahdaerah kabupaten terdekat, seperti Lubuk Linggau, Kepayang, Lebong, Kota Bengkulu, Palembang, Bukit Tinggi, dan bahkan dari Pulau Jawa.

Perkembangan yang sangat pesat dari Jurusan Tarbiyah dan Jurusan Syariah sedikit banyak berpengaruh negatif pada perkembangan Jurusan Dakwah. Mahasiswa baru lebih memilih Jurusan Tarbiyah dan Jurusan Syariah sebagai jurusan yang dianggap lebih memiliki prospek kerja yang lebih baik dibandingkan Jurusan Dakwah. Hal ini bisa dilihat dari jumlah penerimaam mahasiswa baru dari tahun ke tahun yang terus mengalami penurunan.

Berdasarkan penelitian pendahuluan dilapangan ditemukan banyak faktor yang menyebabkan Program Studi Jurusan Dakwah mengalami

\footnotetext{
${ }^{1}$ Buku Pedoman Akademik dan Kode Etik Mahasiswa, STAIN Curup 2010
} 
kemunduruan. Baik yang berasal dari faktor internal maupun eksternal. Faktor Internal kelembagaan; pertama, belum adanya survey kepada masyarakat, survey ini merupakan deteksi dini untuk mengetahui keinginan dan kebutuhan masyarakat terhadap Program Studi Komunikasi Penyiaran Islam. Kedua, selain kurangnya tenaga pendidik yang professional, kurikulum yang belum tepat ${ }^{2}$ juga kurangnya sarana dan prasarana kegiatan belajar dan mengajar, pada akhirnya menyebabkan kemerosotan Jurusan Dakwah, baik secara kuantitas maupun kualitasnya. Ketiga, lemahnya jaringan promosi dan paradigma yang tidak mengikuti perkembangan menjadi faktor utama melemahnya Program Studi Komunikasi Penyiaran Islam (Prodi KPI).

Pencitraan yang tidak diperbaharui menyebabkan Prodi KPI masih dianggap oleh sebagian besar masyarakat hanya sebagai pencetak jurujuru dakwah, yang secara sosial tidak memberikan peluang yang lebih baik untuk mengembangkan diri. Secara sosiologis (faktor eksternal), terjadi perubahan orientasi masyarakat terhadap dunia pendidikan. Pendidikan dipandang lebih sebagai jalan untuk mendapatkan pekerjaan, meskipun tidak sesuai dengan minat dan bakatnya. Sehingga untuk pendidikan tinggi, masyarakat lebih berorientasi pada jurusan yang lebih memiliki peluang kerja yang lebih besar.

Untuk menanggulangi permasalaha diatas menurut peneliti perlu mengetahui lebih jelas persepsi siswa SMA/MA sederajat di Rejang Lebong tentang Prodi KPI, Jurusan Dakwah, STAIN Curup. Hal ini menjadi penting karena sedikit banyaknya mahasiswa yang memilih Prodi KPI, Jurusan Dakwah, STAIN Curup, tergantung dari persepsi siswasiswi SMA/MA sederajat sebagai target market/sasarannya. Fenomena tersebut menurut hemat peneliti adalah realitas yang penting dan menarik untuk diteliti.

\section{Landasan Teori}

1. Persepsi

Secara bahasa, kata persepsi berasal dari bahasa inggris perception yang artinya penglihatan, perasaan, dan penangkapan. Sementara dalam kamus lengkap Bahasa Indonesia popular, persepsi memiliki pengertian sebagai tanggapan dari sesuatu yang dilihat atau di dengar, atau dapat pula bermakna sebagai proses pengamatan tentang sesuatu

\footnotetext{
${ }^{2}$ Nelson, Analisis Kurikulum Jurusan Dakwah Program Studi Komunikasi Penyiaran Islam STAIN Curup, Fokus vol IX, No.02 desember 2009, 92
} 
objek dengan menggunakan panca indera. ${ }^{3}$ Dalam kamus istilah konseling dan terapi, Persepsi dimaknai sebagai hal yang menunjuk pada suatu kesadaran tunggal dari proses pengindraan saat tampilnya suatu stimulus. ${ }^{4}$

Beberapa pengertian persepsi yang telah dikemukakan dalam sub bab ini yang ditinjau dari segi bahasa, persepsi secara sederhana dapat diartikan sebagai respon dari stimulus yang diserap oleh panca indra manusia. Selanjutnya akan dijelaskan mengenai pengertian persepsi dari segi istilah yang dikemukakan oleh para pakar dalam beberapa literature sebagai berikut; persepsi psikologi adalah proses pencarian informasi untuk dipahami. Alat untuk memperoleh informasi tersebut adalah penginderaaan (penglihatan, pendengaran, peraba dan sebagainya). Sebaliknya, alat untuk memahaminya adalah kesadaran atau kognisi. ${ }^{5}$

Menurut Bilson simamora persepsi adalah "bagaimana kita melihat dunia sekitar kita". Secara formal, persepsi dapat didefenisikan sebagai suatu proses, dengan cara seseorang menyeleksi, mengorganisasikan, dan menginterprestasikan stimulus dalam suatu gambaran dunia yang berarti dan menyeluruhngan. ${ }^{6}$ Pernyataan Bilson tidak jauh berbeda dengan pernyataan Robbins bahwa persepsi merupakan suatu proses dimana individu mengorganisasikan dan menginterprestasikan kesan sensori mereka untuk memberi arti pada lingkungan mereka.

Menurut pendapat David Krech disimpulkan bahwa persepsi adalah proses kognitif yang kompleks dan menghasilkan suatu gambar unik tentang kenyataan yang barangkali sangat berbeda dengan kenyataannya. 8 Persepsi adalah suatu proses aktif, setiap orang memperhatikan, mengorganisasikan, dan menafsirkan semua

\footnotetext{
${ }^{3}$ Bambang Mardijanto, Kamus Lengkap Bahasa Indonesia populer, (Surabaya; Bintang Timur, 1996), 481

${ }^{4}$ Andi Mappiare, Kamus Istilah Konseling dan Terapi, (Jakarta: PT. Raja Grafindo Persada, 2006), 239

5 Sarlito Wirawan Sarwono, Psikologi Sosial Individu Dan Teori-Teori (Jakarta: Balai Pustaka, 2002), Cet Ke-3, 94

${ }^{6}$ Bilson Simamora, Panduan Riset Prilaku Konsumen (Jakarta: PT. Garamedia Utama, 2002), 102 $\mathrm{Ke}-5,46$

${ }^{7}$ Stephen P. Robbins, Prinsip-Prinsip Prilaku Organisasi(Jakarta: Erlangga,2002), Cet.

${ }^{8}$ Miftah Thoha, Perilaku Organisasi, Konsep Dasar dan Aplikasinya (Jakarta: PT. Raja Grafindo Persada, 2005), 125
} 
pengalamannya secara selektif. ${ }^{9}$ Persepsi adalah proses internal yang memungkinkan kita memilih, mengorganisasikan, dan menafsirkan rangsangan dari lingkungan kita, dan proses tersebut mempengaruhi prilaku kita. $^{10}$

Persepsi adalah inti komunikasi, sedangkan penafsiran (interprestasi) adalah inti persepsi, yang identik dengan penyandianbaik (decoding) dalam proses komunikasi. ${ }^{11}$ Hal ini jelas nampak pada definisi yang dikemukakan oleh Jhon R. Wenburg dan William W. Wilmot: "Persepsi dapat didefinisikan sebagai cara organisme memberi makna."

Jalaluddin Rakhmat dalam bukunya yang berjudul Psikologi Komunikasi dijelaskan bahwa persepsi adalah pengalaman tentang objek, peristiwa atau hubungan-hubungan yang diperoleh dengan menyimpulkan informasi dan menafsirkan pesan. Persepsi ialah memberikan makna pada stimulasi inderawi. ${ }^{13}$

Pernyataan dari beberapa ahli tentang persepsi dapat disimpulkan bahwa persepsi merujuk pada cara kita menginterpretasikan atau mengerti pesan yang diproses oleh indera kita. Proses persepsi didahului oleh proses sensasi.

Sensasi merupakan tahap paling awal dalam penerimaan informasi. Sensasi berasal dari kata sense, yang artinya alat indera, yang menghubungkan organism dengan lingkungannya. Sensasi adalah proses menangkap stimuli melalui alat indera. Proses sensasi terjadi saat alat indera mengubah informasi menjadi implus-implus saraf yang dimengerti oleh otak.

\section{Faktor-faktor Yang Mempengaruhi Persepsi}

Sejumlah faktor bekerja untuk membentuk dan kadang memutar balik persepsi. Faktor-faktor ini dapat berada pihak pelaku persepsi (perciiver), dalam objeknya atau target yang dipersepsikan, atau dalam konteks dari situasi dalam mana persepsi itu dilakukan. Ketika seorang individu melihat suatu sasaran dan berusaha menginterprestasikan apa

${ }^{9}$ Stewart L. Tubbs dan Sylvia Moss, Human Communication, Prinsip-Prinsip Dasar, Deddy Mulyana, (Bandung: PT. Remaja Rosdakarya, 2001), Cet. Ke-3, 59

${ }^{10}$ Udai Pareek, Perilaku Organisasi (Jakarta: PT. Ikrar Mandiri, 1996), 13

${ }^{11}$ Deddy Mulyana, Ilmu Komunikasi Suatu Penganta (Bandung: PT. Remaja Rosdakarya, 2007), Cet, Ke-7, 167

${ }^{12}$ John R. Wenburg dan William W. Wilmot, The Personal Communication Process, New York: John Wiley \& Sons, 1973, 113

${ }^{13}$ Jalaluddin Rakhmat, Psikologi komunikasi (Bandung: PT. Remaja Rosdakarya, 2007), Cet. Ke-24, 51 
yang ia lihat, interprestasi itu sangat dipengaruhi oleh karakteristik pribadi individu yang melihat. Karakteristik pribadi yang mempengaruhi persepsi meliputi sikap, kepribadian, motif, kepentingan, pengalaman masa lalu dan harapan. ${ }^{14}$

Sementara Jalaluddin Rakhmat dalam bukunya menyatakan bahwa faktor yang sangat mempengaruhi persepsi adalah perhatian. ${ }^{15}$ Selain faktor perhatian yang mempengaruhi persepsi, Persepsi seperti juga sensasi, ditentukan oleh faktor personal dan faktor situiasional. David Krech dan Richard S. Cructchfield menyebutkan sebagai faktor fungsional dan struktural. ${ }^{16}$

a. Faktor Perhatian

Kenneth E. Andersen menyatakan bahwa perhatian adalah proses mental ketika stimuli yang menjadi menonjol dalam kesadaran pada saat stimuli lainnya melemah. ${ }^{17}$

Berbagai macam faktor-faktor perhatian yang berasal dari luar maupun dari dalam dapat mempengaruhi proses seleksi persepsi. Adapun faktor-faktor dari luar yang terdiri dari pengaruh lingkungan luar antara lain: intensitas, ukuran, keberlawanan, pengulangan, gerakan dan hal-hal yang baru berikut ketidak asingan. ${ }^{18}$

Sedangkan faktor internal yang mempengaruhi perhatian kita, yakni: faktor-faktor biologis, faktor-faktor sosiopsikologis, dan juga motif sosiogenis, sikap. Kebiasaan serta kemampuan. ${ }^{19}$

\section{b. Faktor Fungsional}

Faktor fungsional berasal dari kebutuhan, pengalaman, masa lalu dan hal-hal lain yang termasuk apa yang kita sebut sebagai faktor faktor personal.

Selain mempersepsi stimuli secara selektif, kita juga cenderung mengorganisasikan stimuli secara selektif, artinya, stimuli diurutkan dan selanjutnya disajikan menjadi sebuah gambaran yang menyeluruh, lengkap dan dapat di indera. ${ }^{20} \mathrm{Di}$ antara karakteristik pribadi yang

\footnotetext{
${ }^{14}$ SP. Robbin, Op.Cit., 124

${ }^{15}$ Jalaluddin Rakhmat, Psikologi Komunikasi, 52

${ }^{16}$ Ibid, 51

${ }^{17}$ Ibid, 52

${ }^{18}$ Miftah Thoha, Op.Cit., 149

${ }^{19}$ Ibid., 154

${ }^{20}$ Stewart L. Tubbs, Op.Cit., 19
} 
lelevan yang mempengaruhi persepsi adalah sikap, motif, kepentingan atau minat, pengalaman masa lalu, dan pengaharapan (ekspektasi). ${ }^{21}$

c. Faktor-faktor Struktural

Faktor-faktor struktural berasal semata-mata sifat dari sifat fisik dan efek-efek saraf yang ditimbulkan pada sistem saraf individu.

Krech dan Crutchfield melahirkan dalil persepsi yang ke dua: medan perseptual dan kognitif selalu diorganisasikan dan diberi arti. Mengorganisasikan stimuli dengan melihat konteksnya. Walaupun stimuli yang kita terima itu tidak lengkap, kita akanmengisinya dengan interprestasi yang konsisten dengan rangkaian stimuli yang kita persepsi. ${ }^{22}$

\section{Subproses dalam Persepsi}

Ada beberapa subproses dalam persepsi yang menjadi bukti bahwa persepsi merupakan hal yang komplek dan interaktif.

Subproses pertama yang dianggap penting ialah stimulus atau situasi yang hadir. Situasi yang dihadapi itu mungkin bisa berupa stimulus penginderaan dekat dan langsung atau berupa bentuk lingkungan sosiokultur dan fisik yang menyuluruh. ${ }^{23}$

Subproses selanjutnya adalah registrasi, interprestasi, dan umpan balik (feedback). Dalam masa registrasi, suatu gejala yang anmpak ialah mekanisme fisik yang berupa penginderaan dan syaraf seseorang terpengaruh, kemampuan fisik untuk mendengar dan melihat akan mempengaruhi persepsi. Dalam hal ini seseorang mendengar atau melihat informasi terkirim padanya. Mulailah ia mendaftar semua informasi yang terkirim dan terlihat padanya. Setelah terdaftarnya semua informasi yang samapai kepada seseorang subproses berikut yang bekerja ialah interprestasi merupakan suatu aspek kognitif dari persesi yang amat sangat penting. Proses interprestasi ini tergantung pada carapendalaman (learning), motivasi, dan kepribadian seseorang. Pendalaman, motivasi, kepribadian seseorang akan berbeda dengan orang lain. Oleh karena itu, interprestasi terhadap suatu informasi yang sama akan berbeda anatara satu orang dengan orang lain. ${ }^{24}$

\footnotetext{
${ }^{21}$ SP. Robin, Op.Cit., 16-17

${ }^{22}$ Udai Pareek, Op.Cit., 124

${ }^{23}$ Miftah Thoha, Op.Cit., 145-146

${ }^{24}$ Miftah Thoha, Ibid., 146
} 
Subproses terakhir adalah umpan balik (feedback). Subproses ini dapat mempengaruhi persepsi seseorang. Sebagai contoh, seorang karyawan yang melaporkan hasil kerjanya kepada atasannya, kemudian mendapat umpan balik dengan meliahat raut muka atasannya. Kedua alisnya naik ke atas, bibirnya mengatup rapat, matanya tidak berkedip, dan kemudian terdengar suaranya bergumam seperti mau ditelan sendiri. Feedback semacam ini membentuk persepsi tersendiri bagi karyawan tersebut. Bagi atasan tersebut barang kali heran bahwa bawahannya mampu melaksanakan tugasnya dengan baik, dan diamdiam dia memujinya. Tetapi persepsi karyawan, dia telah berbuat salah dan tidak membawa kepuasan bagi atasannya. ${ }^{25}$

\section{Pengertian Siswa Atau Peserta Didik}

Dalam kamus besar bahasa Indonesia, kata siswa diartikan sebagai murid yaitu orang (anak) yang sedang berguru (belajar, bersekolah). ${ }^{26}$ Dalam undang-undang Republik Indonesia No. 20 Tahun 2003 tentang sistem Pendidikan Nasional disebutkan bahwa siswa atau peserta Didik merupakan salah satu anggota masyarakat yang berusaha mengembangkan dirinya melalui proses pembelajaran yang tersedia pada jalur, jemjang dan jenis pendidikan tertentu. ${ }^{27}$

Anak didik atau proses didik adalah anak yang belum dewasa, yang memerlukan usaha, bantuan bimbingan orang lain untuk menjadi dewasa, sehingga dapat melaksanakan tugasnya sebagi mahluk Tuhan, sebagai umat manusia, sebagai Warga Negara, sebagai anggota masyarakat dan sebagai suara pribadi atau individu. ${ }^{28}$

Anak didik adalah anak yang sedang tumbuh dan berkembang, baik secara fisik maupun logis untuk mencapai tujuan pendidikannya melalui lembaga pendidikan. Anak didik atau siswa merupakan masukan (input) utama dalam proses belajar menagjar, karena siswa berkemampuan untuk aktif belajar bagi dirinya di seluruh hasil serta penataan pengajaran atau agar siswa dapat menjalankan tugas belajarnya secara efektif dan efisien. ${ }^{29}$

1. Karakteristik atau sifat Khas Peserta Didik antara lain:

\footnotetext{
${ }^{25}$ Miftah Thoha, OpCit., 146-147

${ }^{26}$ Tim Penyusun Kamus Pusat Pembinanaan dan Pengembangan, Kamus besar Bahasa Indonesia, Jakarta: Balai Pustaka, 2002, 601

${ }^{27}$ Undang- Undang Republik Indonesia No. 20 Tahun 2003 tentang Sistem Pendidikan Nasional , Jakarta: CV. Jaya Abadi , 2003, .5

${ }^{28}$ Abu Ahmadi dan Nur Unbiyati, ilmu pendidikan , Jakarta: Rineka Cipta, 2001, 251

${ }^{29}$ A. Samansa, Sistem Pengajaran, Yogyakarta: konisius, 1992, 14
} 
a. Anak didik adalah seseorang yang belum dewasa atau belum memperoleh kedewasaan, ia masih menjadi tanggung jawab seseorang pendidik tertentu.

b. Anak didik adalah anak yang sedang berkembang, sejak lahir sampai meninggal anak mengalami perkembangan. Karena itu, pendidik harus membantu membimbing perkembangan anak. Baik perkembangan jiwanya, pengetahuannya, dan penguasaan diri terhadap lingkungan sosialnya.

c. Dasar hakiki anak adalah dapat dididik dan harus dididik, karena anak mempunyai bakat dan disposisi-disposisi yang memungkinkan pendidikan.

2. Ciri Khas Anak Didik

a. Individu yang memiliki potensi fisik dan psikis yang khas, sehingga merupakan insan yang unik.

b. Individu yang sedang berkembang yang membutuhkan bimbingan individual dan perlakuan yang manusiawi.

c. Individu yang memiliki kemampuan mandiri, oleh karena itu pendidik harus memberi kesempatan dan mendorong peserta didik agar setapak demi setapak dapat bediri sendiri dalam segala hal.

Beberapa hal yang perlu dipahami dalam masalah anak didik adalah:

a. Anak didik bukan miniatur orang dewasa, ia mempunyai dunia sendiri, sehingga metode belajar mengajar tidak boleh dismakan dengan orang dewasa.

b. Anak didik mengikuti periode-periode perkembangan tertentu dan mempunyai pola perkembangan serta tempo iramanya.

Dalam psikologi perkembangan disebutkan bahwa periodesasi manusia pada dasarnya dapat dibagi menjadi lima tahapan, yaitu:

1. Tahap Asuhan (0,0-2-0 tahun), pada tahun ini, anak belum memiliki kesadaran dan daya intelektual, ia hanya mampu menerima rangsangan yang bersifat biologis dan psikologis melalui air susu ibunya. Pada fase ini belum dapat diberikan edukasi secara langsung.

2. Tahap Pendidikan Jasmani Dan Pelatihan Panca Indera (Usia 2,0-12,0 tahun), pada tahap ini anak mulai memiliki potensipotensi biologis, pedagogis dan psikologis. Oleh karena itu, pada 
tahap ini mulai diperlakukan adanya pembinaan, pelatihan bimbingan, pengajaran dan pendidikan yang disesuaikan bakat, minat dan kemampuannya.

3. Tahap pembentukan Watak Dan Pendidikan Agama (Usia 12,020,0 tahun), pada tahap ini, anak mengalami perubahan biologis yang drastis, postur tubuh hampir menyamai orang dewasa walaupun taraf kematangan jiwanya belum mengimbanginya.

4. Tahap Kematangan (Usia 20,0-30,0 tahun) pada tahap ini, anak telah beranjak menjadi dewasa, yaitu dewasa dalam arti sebenarnya, mencangkup kedewasaan biologis, sosial psikologis dan kedewasaan religius. Pada fasa ini, mereka sudah mempunyai kematangan dalam bertindak, bersikap dan mengambil keputusan untuk menentukan masa depannya sendiri.

5. Tahap Kebijakan (Usia 30 - meninggal), pada tahap ini manusia telah menemukan jati dirinya yang hakiki, sehingga tindakkannya penuh dengan kebijaksanaan yang mampu memberi naungan dan perlindungan bagi orang lain.

c. Anak didik memiliki kebutuhan dan menuntut untuk memenuhi kebutuhan itu semaksimal mungkin.

d. Anak didik memiliki perbedaan anatara individu dengan individu yang lain, baik perbedaan yang disebabakan dari faktor endogen (fitrah) maupun ekogen (lingkungan) yang mempengaruhinya.

e. Anak didik dipandang sebagai kesatuan sistem manusia. Maka pribadi anak didik walaupun terdiri dari banyak segi, merupakan satu kesatuan jiwa raga(cipta, rasa dan karsa).

f. Anak didik merupakan objek pendidikan yang aktif dan kreatif serta produktif. ${ }^{30}$

\section{Metode Penelitian}

Jenis Penelitian

Jenis penelitian ini adalah penelitian deskriptif. Menurut $H$. Nawawi penelitia deskriptif adalah prosedur pemecahan masalah yang diteliti dengan memberikan gambaran keadaan subjek/objek penelitian

30 Muhaimin dan Abdul Mujih, Pemikiran Pendidikan Islam, Kajian Filosofi Dan Kerangka Dasar Operasionalisasinya, Bandung: Trigonda Karya, 1993, Cet. Ke-1 h. 178-181 
pada saat sekarang berdasarkan fakta-fakta yang tampak atau sebagaimana adanya. ${ }^{31}$

Sumber dan Lokasi Penelitian

Sumber data dalam penelitian ini disesuiakan dengan situasi dan kondisi di lapangan dengan tetap mengacu pada permasalahan yang akan diteliti. Data yang dibutuhkan dibedakan atas data primer dan data sekunder. Data primer diperoleh melalui wawancara mendalam dan pengamatan langsung. Sumber data primer tersebut adalah, siswa-siswi MAN Curup dan Pesantren Ar-Rahmah Curup.

Selain data primer, penelitian ini juga membutuhkan data sekunder yaitu, responden (siswa-siswi SMU Sederajat), ini perlu sebagai pendukung utama informasi yang diperoleh melalui kuesioner, dan pengamatan langsung. Atas dasar bahwa pengumpulan data melalui kuesioner hanya sebagai data sekunder, maka persepsi siswa yang akan dijadikan responden dibatasi maksimal 150 orang. Jumlah ini didasarkan pada pertimbangan efektifitas dan efisiensi, baik tenaga, waktu, dan biaya.Penelitian ini meliputi dua lokasi penelitian; MAN Curup, dan Pesantren MA Ar-Rahmah Curup.

Instumen Penelitian

Instrumen penelitian adalah alat yang digunakan untuk mengumpulkan data dalam penelitian. Penggunaan peneliti sebagai instrumen penelitian bertujuan untuk mendapatkan data yang valid. Hal ini dapat dipenuhi karena peneliti langsung ke lapangan melakukan pengamatan dan wawancara dengan informan serta dibekali dengan pengetahun dan pengenalan terhadap lokasi penelitian. Menurut Nasution yang dikutip oleh Sugiono: ${ }^{32}$

"Dalam penelitian kualitatif, tidak ada pilihan lain daripada menjadikan manusia sebagai instrumen penelitian utama. Alasannya ialab babwa segala sesuatunya belum mempunyai bentuk yang pasti. Masalahnya, focus, penelitian, prosedur penelitian, bipotesis yang digunakan, babkan hasil yang diharapkan, itu semuanya tidak dapat ditentukan secara pasti dan jelas sebelumnya. Segala sesuatu masib perlu dikembangkan sepanjang penelitian itu. Dalam keadaan yang serba tidak pasti dan tidak jelas itu, tidak ada piliban lain dan hanya peneliti itu sendiri sebagai alat satusatunya yang dapat mencapainya"

Teknik Pengumpulan Data

\footnotetext{
${ }^{31}$ Hadari Hanawi, Metode Penelitian Bidang Sosial (Gadjah Mada University Press, Yogyakarta, 1990), 63

${ }^{32}$ Sugiono. Memahami Penelitian Kualitatif (Bandung : Alfabeta, 2006), 60-61
} 
Menurut Deddy Mulyana prosedur pengumpulan data dalam penelitian kuliatatif ini menggunakan metode wawancara, pengamatan, penelaahan dokumen, survei dan data apapun untuk menjelaskan subjek yang diteliti. Ini kemudian disesuaikan dengan kondisi dilapangan ini adalah: ${ }^{33}$

Adapun teknik pengumpulan data yang digunakan pada penelitian

1. Wawancara

Adalah teknik mengumpulkan data dengan cara tanya jawab sepihak yang dikerjakan dengan sistematis dan berdasarkan tujuan penelitian.

2. Kuesioner

Adalah teknik pengumpulan data dengan menggunakan daftar pertanyaan yang harus dijawab oleh responden. Daftar pertanyaan bisa terdiri atas:

a. Pertanyaan tertutup yaitu, responden hanya memilih satu atau lebih jawaban dari beberapa pilihan jawaban yang tersedia.

b. Pertanyaan terbuka yaitu, responden diberikan kesempatan untuk mengemukakan pendapatnya dengan kalimatnya sendiri.

3. Dokumentasi

Adalah teknik pengumpulan data dengan memanfaatkan catatancatatan, rekaman-rekaman elektronik (bila tersedia), arsip-arsip, dan beberapa bahan pustaka yang disimpan dan didokumentasikan oleh lembaga penyiaran.

\section{Teknik Analisis dan Intepretasi Data}

Analisis data bertujuan untuk menyederhanakan sejumlah data ke dalam formula yang lebih muda dibaca dan dipahami. Disesuaikan dengan jenis data yang bertumpu pada wawancara, kuesioner dan dokumentasi. Analisis data dalam penelitian ini menggunkan model analisis data kualitatif. Metode kualitatif mendasarkan diri pada pengambilan kesimpulan atas dasar pemikiran yang logis atas beberapa data yang diperoleh.

Analisis dilakukan untuk memberikan gambaran keterkaitan antara konsep dengan realita melalui analisis deskriptif dalam bentuk kajian

\footnotetext{
${ }^{33}$ Deddy Mulyana, Komunkasi Antarbudaya, Panduan Berkomunikasi Dengan Orangorang yang Berbeda Budaya (Bandung: Remaja Rosda karya, 2000), 201
} 
teoritik dan dalam bentuk fenomena yang diperoleh di lapangan. Kajian teoritik secara mendalam adalah untuk menganalisis persepsi siswa SMA/MA sederajat tentang Prodi KPI Jurusan Dakwah STAIN Curup, studi ini kami fokuskan pada MAN Curup, dan Pesantren MA ArRahmah.

\section{Hasil penelitian dan Pembahasan}

Penelitian ini dilaksanakan pada dua Madrasah Aliyah (MA), yaitu Madrasah Aliyah Negeri (MAN) Curup dan Madrasah Aliyah Ar-Rahmah (MA Ar-Rahmah). Melalui penelitian ini dapat dilihat persepsi siswa MA terhadap Program Studi Komunikasi dan Penyiaran Islam (KPI) jurusan Dakwah Sekolah Tinggi Agama Islam Negeri (STAIN) Curup. Berdasarkan hasil penyebaran angket, observasi, dan wawancara kedua MA tersebut diperoleh hal-hal sebagai berikut:

1. Persepsi Siswa MA Terhadap Prodi KPI Jurusan Dakwah STAIN Curup

a) Persepsi Siswa MA Terhadap STAIN Curup

Persepsi siswa MA terhadap Prodi KPI tidak akan pernah lepas dari persepsi siswa MA tentang STAIN Curup, karena STAIN Curup merupakan lembaga yang menaungi Prodi-Prodi yang terdapat di dalamnya, termasuk Prodi KPI. Berdasarkan hasil pegumpulan data dilapangan, dimana tahap pertama dilakukan penyebaran kuisioner kepada 140 siswa MA, yang terdiri dari 16 siswa MA Ar-Rahmah dan 124 orang siswa MAN Curup. Sebanyak 114 orang (81,4\%) informan mengetahui tentang STAIN Curup, sisanya sebanyak 26 orang $(18,6 \%)$ tidak mengetahui tentang STAIN Curup. Selanjutnya dilakukan wawancara dan observasi mendalam mengenai persepsi siswa MA. Informasi mengenai STAIN Curup sebagian besar informan peroleh dari keluarga, teman, kakak kelas yang melanjutkan kuliah di STAIN Curup, alumni STAIN Curup, maupun media massa khususnya surat kabar dan Radio.

Secara umum persepsi siswa MA terhadap STAIN Curup, antara lain:

a. STAIN Curup merupakan Sekolah Tinggi yang berbasis Agama Islam dan satu-satunya Sekolah Tinggi negeri di Curup.

Sesuai dengan namanya Sekolah Tinggi Agama Islam Negeri, maka STAIN Curup menawarkan berbagai program studi yang tidak lepas dari nilai-nilai Islam. STAIN Curup merupakan satu- 
satunya sekolah tinggi Agama Islam negeri yang berada di Kabupaten Rejang Lebong.

b. STAIN Curup masih diragukan kredibilitasnya.

Opini ini berkembang dikarenakan banyaknya informasi, baik melalui komunikasi antarpersonal, maupun melalui komunikasi massa khususnya media cetak mengenai kesimpang siuran akreditasi sebuah Prodi di STAIN Curup.

c. Persepsi Siswa MA Terhadap Prodi KPI Jurusan Dakwah STAIN Curup.

Persepsi sendiri bukan merupakan produk sekali jadi, ia merupakan sebuah proses mental. Diawali dengan informasi yang ditangkap oleh panca indra, baik melalui indra penglihatan, indra pendengaran, indra penciuman, indra peraba, dan indra perasa. Menurut hasil penelitian sebanyak 120 orang $(85,7 \%)$ siswa MA tidak tahu atau tidak mengenal Prodi KPI, sedangkan sebanyak 20 orang $(14,3 \%)$ mengetahui tentang Prodi KPI. Kedua puluh orang inilah yang menjadi informan inti dalam penelitian ini. Informan memperoleh informasi tentang Prodi KPI, melalui:

a). Orang Lain (Teman, Keluarga, Tetangga, dan Guru di Sekolah)

Sebagai makhluk sosial manusia tidak mungkin tidak berhubungan dan berkomunikasi dengan orang lain. Bahkan dalam pembentukan konsep diri seorang anak banyak dipengaruhi oleh orang lain disekitarnya. Manusia menerima informasi yang ditangkap melalui inderanya sebagai dampak dari interaksi sosial yang dilakukannya. Informasi-informasi inilah yang akan berpengaruh pada tatanan kognitif, afektif maupun bahavioral seseorang. Informasi mengenai Prodi KPI didapat dari teman, tetangga, serta guru MA.

b). Melalui Media Massa

Media massa dengan salah satu fungsinya to inform/ memberikan informasi, dapat menjadi sarana yang tepat untuk beriklan atau promosi. Media massa mampu menjaring audience yang luas, dengan bermacam-macam karakteristik dan stratifikasinya. Radio sebagai salah satu media massa juga mampu menjadi sarana yang tepat untuk 
menyampaikan informasi, selain fungsi-fungsi lain yang menyertainya, yaitu to educate (mendidik), to entertain (menghibur), dan to persuade (mempengaruhi). Radio dengan sifatnya yang adiotif mampu membangkitkan imajinasi, sugesti, dan emosi pendengar. Menurut hasil penelitian, radio Pesona FM menjadi salah satu sarana penyebaran informasi mengenai Prodi KPI.

Selain Radio, media massa lain yang berperan terhadap penyebaran informasi mengeai Prodi KPI adalah surat kabar harian Radar Pat Petulai (RPP). Melalui iklaniklan mengenai STAIN Curup maupun dari pemberitaanpemberitaan mengenai STAIN Curup. Surat Kabar Harian Pat Petulai (SKH RPP) bukan merupakan surat kabar yang asing bagi Prodi KPI, karena banyaknya kerjasama khususnya dibidang jurnalistik, berupa kerjasama dalam Praktek Kuliah Lapangan (PKL) Mahasiwa. Kelebihan media cetak adalah sifatnya yang terekam, sehingga dapat dibaca berulang-ulang, serta menimbulkan perangkat mental yang aktif sehingga menuntut kosentrasi pembaca.

c). Brosur

Sumber informasi lain mengenai Prodi KPI adalah brosur penerimaan mahasiswa baru STAIN Curup. Tentu saja di dalam brosur tidak hanya memuat informasi mengenai Prodi KPI tetapi juga Prodi-Prodi yang ada di STAIN Curup secara keseluruhan. Melalui brosur inilah dapat diketahui gambaran umum mengenai sarana dan prasarana, baik sarana penunjang pendidikan seperti gedung administrasi, ruang kuliah, perpustakaan, laboratorium, dll; sarana dan prasarana penunjang kegiatan mahasiswa seperti sekretariat organisasi mahasiswa, lapangan dan perlengkapan olahraga, dll. Selain dari pada itu, di dalam brosur juga terdapat informasi mengenai jurusan dan prodiprodi yang ada di STAIN Curup.

Proses persepsi selanjutnya adalah informasi akan diproses atau diorganisir. Tidak ada informasi yang mewakili realitas secara utuh. Maka dari pada itu, informasi yang diterima biasanya tidak utuh sehingga informasi yang ada akan dicari kemiripan dengan informasi lainnya, dan juga dilengkapi dengan informasi-informasi lainnya. 
Informasi-informasi yang informan peroleh mengenai Prodi KPI sangatlah dangkal. Sehingga Informasi-informasi itu akan dilengkapi dengan informasi-informasi mengenai Prodi-Prodi lain yang ada di STAIN Curup. Hal ini dapat dilihat dari hasil wawancara mengenai prospek kerja lulusan Prodi KPI STAIN Curup. Dari 20 informan yang tahu tentang Prodi KPI STAIN Curup, sebanyak 8 orang $(40 \%)$ tidak tahu mengenai prospek kerja Prodi KPI STAIN Curup, sebanyak 7 orang (35\%) mengungkapkan bahwa prospek kerja lulusan Prodi KPI STAIN Curup adalah sebagai pendakwah/da'i. Sebanyak 3 orang (15\%) mengungkapkan menjadi guru, dan sebanyak 2 orang $(10 \%)$ mengungkapkan bahwa prospek kerja lulusan STAIN Curup adalah sebagai penyiar.

Proses persepsi selanjutnya adalah penafsiran (interpretasi) dari informasi-informasi yang sudah diproses. Berdasarkan hasil penelitian, persepsi mahasiswa MA terhadap Prodi KPI STAIN Curup antara lain:

a. Prodi KPI STAIN Curup Baik

Sebanyak 9 orang (40\%) informan mengungkapkan bahwa Prodi KPI sudah cukup baik. Menurut Informan, KPI sudah mempunyai sarana dan prasarana yang memadai seperti gedung perkuliahan yang memadai. Persepsi yang baik tentang prodi KPI mereka dapat juga dari sahabat/tetangga/keluarga yang menjadi mahasiswa di Prodi KPI. Melalui informasi orang lain (keluarga.teman/masyarakat) disekeliling mereka, informan memperoleh sedikit informasi tentang sistem perkuliahan yang berbeda dengan sitem belajar di sekolah dan citra dosen Prodi KPI yang secara umum dinilai baik. Sedangkan dari segi kelengkapan penunjang proses akademis, seperti peralatan penunjang akademis, laboratorium, kurikulum, informan belum mengetahui.

b. Prodi KPI STAIN Curup masih diragukan

Sebanyak tiga orang (15\%) informan berpersepsi bahwa Prodi KPI masih diragukan. Persepsi ini timbul karena pemberitaan media yang gencar beberapa waktu yang lalu mengenai masalah akreditasi Prodi BK STAIN Curup. Melalui media massa akhirnya timbul diskusi di masyarakat yang akhirnya menimbulkan opini publik termasuk opini di siswa MA yang mengeneralisasi secara berlebihan bahwa Prodi-Prodi di STAIN Curup masih diragukan atau belum profesional dikarenakan tersandung masalah kreditasi. Sebelum ada pemberitaan di media massa, informan mengaku 
belum tahu tentang masalah akreditasi. Persepsi mereka bahwa salah satu syarat menjadi Prodi yang baik adalah sudah terakreditasi yang tentunya berdampak pada prospek kerja kedepan.

c. Tidak begitu mengenal

Sebanyak 8 orang (40\%) tidak begitu mengenal prodi KPI. Informasi tentang Prodi KPI hanya sebatas pengetahuan bahwa salah satu Prodi di STAIN Curup adalah Prodi KPI, bagaimana prodi KPI, prospek kerja dan lainnya tidak mereka ketahui. Jadi informasi mengenai Prodi KPI masih sangat terbatas.

2. Faktor-faktor apakah yang mempengaruhi persepsi siswa MAN Curup dan MA Ar-Rahmah terhadap Prodi KPI

Terbentuknya persepsi siswa MA terhadap Prodi KPI dipengaruhi oleh beberapa faktor. Faktor-faktor yang mempengaruhi persepsi siswa MA antara lain:

a. Pengalaman

Pengalaman sangat berpengaruh terhadap proses persepsi. Pengalaman menjadi rambu-rambu acuan dalam berprilaku. Pengalaman juga membatu dalam pengambilan keputusan. Pengalaman tidak hanya berasal dari diri sendiri, berupa kejadiankejadian yang dialami dan dijadikan referensi informasi. Pengalaman juga bisa didapat dari orang lain dari interaksi dengan lingkungan sosial dan media massa. Dalam interaksi keseharian, manusia tak luput dari komunikasi. Disadari atau tidak, pertukaran pesan yang terjadi terkadang menjadi sarana transformasi pengalaman. Banyak pengalaman-pengalaman orang lain yang dikemas dalam program acara televisi menjadi sebuah program acara yang mempunyai rating yang bagus. Tak dipungkiri, saat ini media massa sudah menjadi sumber referensi yang mumpuni.

Berdasarkan hasil penelitian, sebanyak 12 orang $(60 \%)$ informan mempuyai teman/saudara/tetangga yang kuliah di Prodi KPI, sedangkan sisanya 8 orang $(40 \%)$ tidak. Melalui interaksi dengan teman, keluarga, maupun tetangga yang kuliah di Prodi KPI, mereka memperoleh pengalaman-pengalaman tentang suasana belajar di bangku kuliah. Sebanyak 16 orang (80\%) informan pernah berkunjung ke STAIN baik dalam rangka kegiatan sekolah maupun hanya sekedar melihat aktifitas sore di STAIN Curup, sedangkan 4 orang (20\%) belum pernah ke STAIN Curup. Melalaui kunjungan ke STAIN Curup informan 
mengaku mendapat sedikit gambaran tentang suasana di STAIN Curup. Melalui informasi dari teman/keluarga/masyarakat sekitar serta tambahan informasi dari media massa, sehingga terangkum bahwa Prodi yang ideal adalah Prodi yang sudah terakreditasi, prospek kerja menjanjikan/mempunyai bidang kerja yang luas, mempunyai fasilitas penunjang proses belajar dan mengajar yang lengkap.

b. Motivasi, minat, dan kebutuhan

Motivasi dan minat sangat menentukan dalam proses seleksi. Begitu banyak rangsangan/stimuli dari luar, tetapi tidak semuanya dapat kita terima. Motivasi dan minat mejadi salah satu acuan untuk menentukan dan memilih rangsangan yang akan kita respon dari begitu banyak rangsangan yang ada.

Mata pelajaran favorit siswa MAN Curup dan MA Ar-Rahmah

\begin{tabular}{|l|l|}
\hline Jumlah Informan & Mata Pelajaran Favorit \\
\hline 8 orang $(40 \%)$ & $\begin{array}{l}\text { Bahasa Arab, Ilmu kalam, SKI (Sejarah } \\
\text { Kebudayaan Islam) }\end{array}$ \\
\hline 6 orang $(30 \%)$ & Matematika, Kimia, Biologi) \\
\hline 6 orang $(30 \%)$ & Bhs. Inggris, Bhs. Indonesia, Ekonomi \\
\hline
\end{tabular}

Ekstrakurikuler Yang diikuti siswa MAN Curup dan MA Ar-Rahmah

\begin{tabular}{|l|l|}
\hline Jumlah Informan & Ekstrakurikuler yang diikuti \\
\hline 6 orang $(30 \%)$ & Risma \\
\hline 5 orang $(25 \%)$ & Tidak ikut organisasi \\
\hline 3 orang $(15 \%)$ & Pramuka \\
\hline 1 orang $(5 \%)$ & Teater \\
\hline 1 orang $(5 \%)$ & Paskibraka \\
\hline
\end{tabular}

Organisasi yang diikuti siswa MAN Curup dan MA Ar-Rahmah

\begin{tabular}{|l|l|}
\hline Jumlah Informan & \multicolumn{1}{|c|}{ Organisasi ekstrasekolah yang diikuti } \\
\hline 9 orang $(45 \%)$ & Risma \\
\hline 7 orang $(35 \%)$ & Tidak ikut organisasi \\
\hline 3 orang $(15 \%)$ & Forum Anak Rejang Lebong (FOREL) \\
\hline
\end{tabular}


Berdasarkan tabel 2, 3, 4 di atas dapat kita lihat bahwa sebagian besar informan mempunyai minat yang tinggi terhadap pelajaran agama, organisasi keagamaan, baik intra maupun ekstra sekolah.

Para ahli sepakat bahwa kebutuhan paling dasar adalah kebutuhan akan makanan, kebutuhan fisik, tempat tinggal, sekl, dan lainnya. Barulas setelah kebutuhan dasar ini terpenuhi maka kebutuhan-kebutuhan lain akan menyertai, seperti kebutuhan akan pengakuan dan eksistensi diri, rasa aman, hiburan, dan lainnya. Kebutuhan akan menimbullkan dorongan/motivasi yang kuat dan usaha-usaha untuk memenuhinya.

Menurut hasil penelitian, semua informan berencana meneruskan pendidikan setelah lulus sekolah. Sebanyak 14 orang (70\%) akan melanjutkan kuliah, 3 orang $(15 \%)$ berencana mengikuti tes pendidikan Polisi/TNI, dan 3 orang (15\%) akan melanjutkan kuliah sambil bekerja. Ini menunjukkan bahwa siswa MA mempunyai kebutuhan akan informasi mengenai tempat kuliah.

c. Harapan

Setiap individu pasti mempunyai harapan dan cita-cita dalam hidupnya. Harapan akan menimbulkan motivasi untuk pencapaiannya. Dibutuhkan usaha untuk merealisasikan hapan dan cita, karena harapan tanpa usaha hanya sebatas angan-angan.

Berdasarkan hasil penelitian semua informan bercita-cita untuk meneruskan sekolah ke jenjang yang lebih tinggi. Harapan dan citacita informan antara lain: 11 orang (55\%) ingin menjadi tenaga pengajar, 3 orang $(15 \%)$ ingin menjadi polisi/TNI, 3 orang $(15 \%)$ ingin menjadi bidan, 3 orang $(15 \%)$ ingin menjadi pengsaha.

d. Stereotip

Stereotip adalah generalisasi secara berlebihan yang menimbulkan pencitraan terhadap hal yang sama dalam kelompok tersebut. Berdasarkan hasil penelitian stereotip tentang Prodi KPI adalah mempersepsi secara serupa bahwa semua Prodi di STAIN Curup tidak terakreditasi termasuk Prodi KPI. Stereotip juga menghilangkan ciri khas/pembeda, termasuk juga pada Prodi KPI, bahwa lulusan prodi KPI menjadi digeneralisasi sama dengan prodi lainnya, antara lain menjadi guru yang sesungguhnya merupakan prospek kerja lulusan Jurusan Tarbiyah.

\section{Penutup}




\section{Kesimpulan}

Persepsi merupakan proses mental yang diawali dengan informasi yang ditangkap oleh (panca indra, baik melalui indra penglihatan, indra pendengaran, indra penciuman, indra peraba, dan indra perasa). Informasi mengenai Prodi KPI didapat dari keluarga/teman/tetangga yang sedang maupun telah selesai menempuh pendidikan di STAIN Curup, media massa yaitu melalui iklan penerimaan mahasiswa baru Surat Kabar Harian Radar Pat Petulai, dan Radio Pesona FM, serta dari brosur penerimaan mahasiswa baru. Kemudian informasi tersebut akan diorganisir dan diinterpretasikan. Berdasarkan hasil penelitian, persepsi siswa MAN Curup dan MA ArRahmah terhadap Prodi KPI Jurusan Dakwah STAIN Curup, antara lain: Prodi KPI sudah cukup baik, Prodi KPI masih diragukan, serta belum terlalu mengenal Prodi KPI.

Terbentuknya persepsi siswa MA terhadap Prodi KPI dipengaruhi oleh beberapa faktor. Faktor-faktor yang mempengaruhi persepsi siswa MA antara lain: pengalaman, motivasi,minat dan kebutuhan, harapan, serta stereotip.

\section{Saran}

1. Diharapkan kepada pengelola Prodi KPI untuk melakukan sosialisasi ke sekolah-sekolah maupun ke masyarakat tentang keberadaan Prodi KPI, prospek kerja, kurikulum dan fasilitas penunjang pedidikan.

2. Diharapkan kepada Civitas Akademika STAIN Curup untuk memberikan penjelasan dan informasi secara lengkap kepada masyarakat, khususnya tentang Prodi KPI dan Prodi-Prodi lainnya di STAIN Curup.

\section{Daftar Kepustakaan}

Ahmadi, Abu dan Nur Unbiyati, ilmu pendidikan , Jakarta: Rineka Cipta, 2001

Hanawi, Hadari. Metode Penelitian Bidang Sosial, Gadjah Mada University Press, Yogyakarta, 1990

Mappiare, Andi. Kamus Istilah Konseling dan Terapi, Jakarta: PT. Raja Grafindo Persada, 2006

Mardijanto, Bambang Kamus Lengkap Bahasa Indonesia populer, Surabaya:; Bintang Timur, 1996 
Mulyana, Deddy. Komunkasi Antarbudaya, Panduan Berkomunikasi Dengan Orang-orang yang Berbeda Budaya, Remaja Rosda karya, Bandung, 2000

Muhaimin dan Abdul Mujih, Pemikiran Pendidikan Islam, Kajian Filosofi Dan Kerangka Dasar Operasionalisasinya, Bandung: Trigonda Karya, 1993

Rakhmat, Jalaluddin. Psikologi komunikasi, (Bandung: PT. Remaja Rosdakarya, 2007), Cet. Ke-24

Sarwono, Sarlito Wirawan. Psikologi Sosial Individu Dan Teori-Teori, (Jakarta: Balai Pustaka, 2002), Cet Ke-3

Samansa, A. Sistem Pengajaran, Yogyakarta: konisius, 1992

Simamora, Bilson. Panduan Riset Prilaku Konsumen, Jakarta: PT. Garamedia Utama, 2002

Sugiono. Memahami Penelitian Kualitatif. Bandung : Alfabeta, 2006

Robbins, Stephen P. Prinsip-Prinsip Prilaku Organisasi, Jakarta: Erlangga,2002

Thoha, Miftah. Perilaku Organisasi, Konsep Dasar dan Aplikasinya, Jakarta: PT. Raja Grafindo Persada, 2005

Tubbs, Stewart L. dan Sylvia Moss, Human Communication, Prinsip-Prinsip Dasar, Deddy Mulyana, Bandung: PT. Remaja Rosdakarya, 2001, Cet. $\mathrm{Ke}-3$

Pareek, Udai. Perilaku Organisasi, Jakarta: PT. Ikrar Mandiri, 1996

Wenburg,John R. dan William W. Wilmot, The Personal Communication Process, New York: John Wiley \& Sons, 1973

Nelson, Analisis Kurikulum Jurusan Dakwah Program Studi Komunikasi Penyiaran Islam STAIN Curup, Fokus vol IX, No.02 desember 2009, hal. 92

Tim Penyusun Kamus Pusat Pembinanaan dan Pengembangan, Kamus besar Bahasa Indonesia, Jakarta: Balai Pustaka, 2002

Undang- Undang Republik Indonesia No. 20 Tahun 2003 tentang Sistem Pendidikan Nasional , Jakarta: CV. Jaya Abadi , 2003 